\title{
Occurrence of DEA1.1 in blood donor dogs in Cuiabá, Mato Grosso, Brazil
}

\section{Ocorrência de DEA 1.1 em cães doadores de sangue em Cuiabá, Mato Grosso, Brasil}

\author{
Mariana Elisa Pereira ${ }^{1}$; Marcela Natacha Aparecida Rocha ${ }^{1}$; Adriane Jorge \\ Mendonça ${ }^{2}$; Arleana do Bom Parto Ferreira de Almeida ${ }^{2}$; Darlan Henrique Canei ${ }^{1}$; \\ Valéria Régia Franco Sousa ${ }^{2 *}$
}

\section{Highlights:}

The occurrence of the blood group DEA 1.1 in donor dogs using the RapidVet ${ }^{\circ}$ kit.

Higher prevalence of DEA 1.1 on male dogs.

Criteria used for donor inclusion.

\begin{abstract}
This study aimed to assess Dog Erythrocyte Antigen (DEA) 1.1 in donor dogs at the Federal University of Mato Grosso, Cuiabá, Brazil, and review the relevant literature. The blood (60 samples; $1.5 \mathrm{~mL}$ volume, each) was collected in separate vacutainer tubes containing ethylenediaminetetraacetic acid and submitted for complete blood count; in addition, the samples were typed by RapidVet ${ }^{\circledR}$ based on agglutination due to specific interaction between DEA 1 antigen at the membrane surface of the erythrocyte and lyophilised murine monoclonal antibody on the test card. DEA1.1 positivity was observed in $81.6 \%$ (49 of 60 ) of test samples, while negative results were obtained in the remaining $18.3 \%$ ( 11 of 60 ). DEA 1.1 positive samples were comprised of $42.8 \%$ of purebred dogs and $38.3 \%$ of mixed breed dogs. With regard to sex in the DEA 1.1 positive group, $48.3 \%$ were male dogs and $33.3 \%$ were female dogs. The blood donor canine population showed high prevalence of DEA 1.1, which confirms that blood typing should be performed prior to blood transfusion in previously sensitised dogs. Key words: Blood type. Blood transfusion. Canine.
\end{abstract}

\section{Resumo}

O objetivo deste trabalho foi avaliar a ocorrência do antígeno eritrocitário DEA (Dog Erythrocyte Antigen) 1.1 nos cães doadores de sangue no Hospital Veterinário Universitário em Cuiabá, Mato Grosso, Brazil. O sangue (60 amostras; 1,5mL cada) Foram coletadas amostras de sangue de 60 cães em tubo a vácuo contendo ácido etilenodiamino tetra-acético (EDTA) para realização de hemograma; adicionalmente, foi realizada tipagem sanguínea com o kit RapidVet $\AA$, que baseia-se na aglutinação devido à interação entre os antígenos DEA 1 do antígeno eritrocitário com os anticorpos monoclonais presentes no cartão. Das amostras testadas, 81,6\% (49 de 60) apresentaram positividade para DEA 1.1,

1 Discentes, Programa de Residência Uniprofissional em Medicina Veterinária, Faculdade de Medicina Veterinária, Universidade Federal de Mato Grosso, UFMT, Cuiabá, MT, Brasil. E-mail: marianaep@gmail.com; marcelanatachavet@gmail.com; darlancanei@hotmail.com

2 Prof ${ }^{\text {as }}$, Faculdade de Medicina Veterinária, UFMT, Cuiabá, MT, Brasil. E-mail: adrianejorge.m@gmail.com; arleferreira@gmail. com; valeriaregia27@gmail.com

* Author for correspondence 
enquanto que apenas $18,3 \%$ (11 de 60 ) foram negativas. Os cães com raça definida representaram $42,8 \%$ das amostras DEA 1.1, já os cães mestiços representaram 38,3\%. Em relação ao sexo dos cães DEA 1.1, foi observada prevalência de 48,3\% em machos e 33,3\% em fêmeas. Este trabalho demonstrou a alta prevalência do grupo DEA 1.1 na população de cães doadores de sangue, o que ratifica a importância da tipagem sanguínea anteriormente à transfusão sanguínea em cães previamente sensibilizados.

Palavras-chave: Tipo sanguíneo. Transfusão sanguínea. Canino.

In general, dogs do not express antibodies to the antigenic groupsofothercaninespecies; nevertheless, alloantibodies may be present in those exposed to organisms that are similar to or homologous with erythrocyte surface antigens, which can lead to cross reaction. Moreover, after sensitisation to a different blood type by transplacental route or blood transfusion, production of anti-erythrocyte antibodies is expected (Santos, 2014). Kirkman (2010) reported that transfusion reactions occur due interaction between the recipient's plasma antibodies with donor erythrocyte antigens, which can cause agglutination and consequent haemolysis of the donor cells.

Among the different blood group systems established in dogs, Dog Erythrocyte Antigen (DEA) has been the most common research focus, and includes seven blood types, while Dal, Kai 1, and Kai 2 were introduced subsequently and are still relatively unclear (Spada et al., 2017).

DEA is classified into DEA 1, DEA 3, DEA 4, DEA 5, DEA 6, DEA 7, and DEA 8 (Hohenhaus, 2004); of which, DEA 1.0 comprises three antigens, DEA 1.1, DEA 1.2, and DEA 1.3 and four phenotypes, 1.1, 1.2, 1.3, and negative (Riond, Schuler, Rogg, Hofmann-Lehmann, \& Lutz, 2011). Dogs with DEA 1 negative phenotype lack the corresponding antigens (Vizzoni \& Medeiros, 2017). In this system, DEA 1.1 is most common and expressed in majority of the dog population worldwide (Riond et al., 2011).

The blood typing methods used in veterinary medicine are based on visualisation of haemagglutination between the red cell's surface antigens and reagent containing specific mono or polyclonal antiserum (Kohn, Classe, \& Weingart, 2014). Giger, Stieger and Palos (2005) described that rapid tests, such as card agglutination test, is an efficient method for identification of DEA 1.1 type; nevertheless, DEA 1.2 positive blood may react weakly, and samples with persistent selfagglutination cannot be applied (Seth, Jackson, Winzelberg, \& Giger, 2012), what was not observed in our study. Rapid tests reflect the advancement in laboratory techniques, but their applicability is limited in routine practice due to high cost.

This study aimed to verify the occurrence of DEA 1.1 in blood donor dogs at the Veterinary Hospital of the Federal University of Mato Grosso, Cuiabá and review the relevant literature.

This study was approved by the Animal Use Ethics Committee (CEUA) of the Federal University of Mato Grosso (Approval number: 23108.174480 / 2016-17).

A total of 60 blood donor dogs (24 female dogs and 36 male dogs) at the Veterinary Hospital of the Federal University of Mato Grosso from October, 2016 to October, 2017 were evaluated. Before the start of the study, forms with the registration data of the dog and those of authorisation to collect the biological sample were signed by each owner and collected for the record.

Inclusion criteria for donors were according to Barreto (2009): Docile personality, good health status with body weight $>26 \mathrm{~kg}$, updated vaccination card, and control of endo and ectoparasites, female dogs not in heat, estrus, or breastfeeding, and age range of 1-8 years; in addition, only dogs with haematological values within the reference limit (Table 1) according to the described by Feldman, Zinkl, Jain and Schalm (2010), were included.

Blood samples of approximately $2 \mathrm{~mL}$ volume were collected from the external jugular vein in a 
vacuum tube containing ethylenediaminetetraacetic acid (EDTA). Each sample was submitted for analysis including complete blood count, total plasma protein measurements, and platelet count by Poche 100 Hematological Analyzer (Roche $^{\circledR}$ Diagnóstica Brasil Ltda, São Paulo, Brazil), and blood smear for light microscopy conference according to Jain (1993), to assess the health of the animals; subsequently, canine DEA 1.1 blood typing with RapidVet ${ }^{\circledR}$ (DMS Laboratory, Flemington, USA) was performed according to the manufacturer's recommendations within 8-hours period after collection.

Table 1

Mean, median and standard deviation of haematological findings in donor dogs tested for DEA 1.1 antigens

\begin{tabular}{cccc}
\hline & Mean & Median & Standard Deviation \\
\hline Hematocrit $(\%)$ & 47.9 & 48 & 4.8 \\
Total leukocytes $\left(10^{3} / \mu \mathrm{l}\right)$ & 12.8 & 12.5 & 3.2 \\
Platelets $\left(10^{3} / \mu \mathrm{l}\right)$ & 252,0 & 240 & 62.3 \\
Total Plasma Proteins $(\mathrm{g} / \mathrm{dl})$ & 7.5 & 7.6 & 0.6 \\
\hline
\end{tabular}

The results are expressed descriptively as mean, median, and standard deviation; these were submitted to descriptive analysis by MS Excel ${ }^{\circledR}$ electronic sheets (Microsoft Corp., Redmond, WA, USA).

In our study, the prevalence of DEA 1.1 was $81.1 \%$, which is higher that of $50-60 \%$ in the canine population in Carli et al. (2017); the discrepancy of results between the studies may be explained by the fact that the donor animals included in our study were conditioned according to the demands of our hospital's practice, which comprises purebred animals and crossbreeds (Table 2).

Table 2

Distribution of the breed and sex of dogs according to occurrence of DEA 1.1.

\begin{tabular}{ccccccc}
\hline \multirow{2}{*}{ BREED } & \multicolumn{2}{c}{ SEX } & \multicolumn{4}{c}{ DEA 1.1 } \\
\cline { 4 - 7 } & Male & Female & \multicolumn{2}{c}{ Positive (n/\%) } & Negative (n/\%) \\
\hline American Bully & - & 1 & 1 & $1.6 \%$ & - & - \\
Boxer & 2 & - & 2 & $3.3 \%$ & - & - \\
Bull Terrier & 1 & - & - & - & 1 & $1.6 \%$ \\
Dalmatian & 1 & 1 & 2 & $3.3 \%$ & - & - \\
German Dog & 1 & - & 1 & $1.6 \%$ & - & - \\
Golden Retriever & 1 & - & 1 & $1.6 \%$ & - & - \\
Labrador Retriever & 5 & 2 & 7 & $11.6 \%$ & - & - \\
German Shepherd & 2 & - & 1 & $1.6 \%$ & 1 & $1.6 \%$ \\
Belgian Shepherd & 3 & - & 1 & $1.6 \%$ & 2 & $3.3 \%$ \\
American Pit Bull & 7 & 5 & 7 & $11.6 \%$ & 5 & $8,3 \%$ \\
Rottweiler & 1 & 2 & 3 & $5 \%$ & - & - \\
MBD* & 12 & 13 & 23 & $38.3 \%$ & 2 & $3.3 \%$ \\
TOTAL & 36 & 24 & 49 & $81.1 \%$ & 11 & $18.1 \%$ \\
\hline
\end{tabular}

* Mixed Breed Dogs. 
DEA 1.1 type was observed in $42.8 \%$ of test samples from purebred dogs and $38.3 \%$ of those from crossbred dogs, of which, the latter corresponds to a lower prevalence rate than $80 \%$ of DEA 1.1 type among crossbred dogs in southern India in Madhavan, Manju and Usha (2014). Among the purebred dogs tested, two were German shepherds, and 50\% were DEA 1.1 type. In agreement, Novais, Fagliari and Santana (2002) reported that DEA 1.1 and DEA 4 were the most common combination type by breed: frequency of $46 \%$ and $35 \%$ in German shepherd dogs and crossbred dogs, respectively. In our study, the number of dogs in each breed category was low, which limited assessment of its relationship with DEA 1.1; nevertheless, DEA 1.1 type was observed in $100 \%$ of Boxer dogs, which corroborates the association of DEA 1.1 with Boxer dogs in Carli et al. (2017).

The reason(s) for the higher prevalence of $48.3 \%$ of DEA 1.1 in the male dogs in our study are unclear, and further studies are needed to clarify this issue. Moreover, female dogs that have already given birth may not be suitable candidates due to potential sensitisation to erythrocyte antigens after delivery. In this context, Blais, Rozanski, Hale, Shaw and Cotter (2009) reported that nulliparous female animals and those with a history of pregnancy achieved similar prevalence rates of alloantibodies, and based on this evidence, recommended that these animals should not be excluded from donor programs.

In our study, DEA 1.1 was strongly prevalent, which may due to autosomal dominance of surface antigen expression in this system (Carli et al., 2017).

Blood typing should be performed prior to blood transfusion to avoid serious adverse reactions, especially in recipient dogs that have been previously sensitised. Advancement of laboratory techniques has enabled rapid tests for routine use in the veterinary field, and popularisation of these methods has concomitantly increased their accessibility.

Our study highlights that clinicians should not avoid blood transfusions based on the high prevalence of DEA 1.1 in the canine population, but should be aware that blood typing tests are necessary to avoid formation of antibodies against the donor dog's erythrocytes.

\section{References}

Barreto, E. P. L. (2009). Transfusão sanguinea em cães: revisão de literatura. Monografia de especialização, Universidade Federal Rural do Semi-Árido, Salvador, BA, Brasil.

Blais, M. C., Rozanski, E. A., Hale, A. S., Shaw, S. P., \& Cotter, S. M. (2009). Lack of evidence of pregnancy-induced alloantibodies in dogs. Journal of Veterinary Internal Medicine, 23(3), 462-465. doi: 10.1111/j.1939-1676.2009.0286.x

Carli, E., Carminato, A., Ravagnan, S., Capello, K., Antognoni, M. T., Miglio, A., Furlanello, T., Proverbio, D., Spada E., Stefani, A., Mutinelli, F. \& Vascellari, M. (2017). Frequency of DEA 1 antigen in 1037 mongrel and purebreed dogs in Italy. BioMed Central Veterinary Research, 13(364). doi: 10.1186/ s12917-017-1286-y

Feldman, B. F., Zinkl, J. G., Jain, N. C., \& Schalm, O. W. (2010) Schalm's veterinary hematology. Philadelphia: Lippincott Williams \& Wilkins.

Giger, U., Stieger, K., \& Palos, H. (2005). Comparison of various canine bloodtyping methods. American Journal of Veterinary Research, 66(8), 1386-1392. doi: 10.2460/ajvr.2005.66.1386

Hohenhaus, A. E. (2004). Importance of blood groups and blood group antibodies in companion animals. Transfusion Medicine Reviews, 18(2), 117-126. doi: 10.1111/j.1751-0813.2005.tb12195.x

Jain, N. C. (1993). Essencials of veterinary hematology. Phildelphia: Lea e Febiger.

Kirkman, E. (2010). Blood groups. Anaesthesia and Intensive Care Medicine, 11(6), 232-235. doi: 10.1016/j.mpaic.2010.02.016

Kohn, B., Classe, G., Weingart, C. Clinical evaluation of the Quick Vet/RapidVet canine dog erythrocyte antigen 1.1 blood-typing test. Journal of Veterinary Diagnostic Investigation, 24(3), 539-545, 2014. doi: $10.1177 / 1040638712442880$

Madhavan, U. N., Manju, K. M., \& Usha, N. P. (2014). Studies on the occurrence of dog erythrocyte antigen 1.1 in dog breeds of Kerala. Malaysian Journal of Veterinary Research, 5(2), 11-13. 
Novais, A. A., Fagliari, J. J., \& Santana, A. E. (2002). DEA (Dog Erythrocyte Antigen) prevalence in dogs from Brazil. In Proceedings of the Congress of the World Small Animal Veterinary Association, Granada, Espanha, 27. Retrieved from www.vin.com/ proceedings/Proceedings.plx?CID=WSAVA2002\& $\mathrm{PID}=2839$

Riond, B., Schuler, E., Rogg, E., Hofmann-Lehmann, R., \& Lutz, H. (2011). Prevalence of dog erythrocyte antigen 1.1 in dogs in Switzerland evaluated with thegel column technique. Schweizer Archiv für Tierheilkunde, 153(8), 369-374. doi: 10.1024/0036$7281 / \mathrm{a} 000223$

Santos, S. C. S. (2014). Avaliação de parâmetros hematológicos e cinética da produção de anticorpos anti-DEA 1.1 em cães pós-transfundidos. Dissertação de mestrado, Departamento Instituto de Ciências da Saúde, Universidade Federal da Bahia, Salvador, Brasil.
Seth, M., Jackson, K. V., Winzelberg, S., \& Giger, U. (2012). Comparison of gel column, card, and cartridge techniques for dog erythrocyte antigen 1.1 blood typing. American Journal of Veterinary Research, 73(2), 213-219. doi: 10.2460/ajvr.73.2.213

Spada, E. A., Proverbio, D. A., Priolo, V. B., Ippolito, D. B., Baggiani, L. A., Perego, R. A., \& Pennisi, M. G. (2017). Dog erythrocyte antigens (DEA) 1, 4, 7 and suspected naturally occurring anti-DEA 7 antibodies in Italian Corso dogs. The Veterinary Journal, 2, 1721. doi: 10.1016/j.tvj1.2017.02.008

Vizzoni, A. G., \& Medeiros, M. A. S. (2017). Imunohematologia veterinária: antígenos eritrocitários caninos. Arquivos de Ciências Veterinárias e Zoologia da UNIPAR, 20(4), 241246. doi: 10.25110/arqvet.v20i4.2017.5682 
